\title{
Impact of Agribusiness Contract on Smallholder Farmers' Incomes in Senegal Delta River and Mauritius
}

\author{
Malick NDIAYE \\ Gaston Berger University PO box 234, Saint-Louis, Senegal
}

\begin{abstract}
Agribusiness is one of the policy options in most countries to ensure food security, reduce poverty and support family farming towards modernization. Under these conditions, farmers and agribusiness companies are entering into agricultural contracts in some developing countries, like Senegal and Mauritius. This research aims to evaluate the impact of agribusiness contracts on farmers' incomes in the Senegal River Delta and Mauritius. The sample surveyed is 270 farmers in Mauritius (93 treated) and 320 in the Senegal Delta (147 treated), coupled with interviews and bibliographic research. To analyze the data, we used the propensity score matching method based on the counterfactual approach. The impact of agricultural contracts on farmers' incomes in Mauritius is $€ 1,648$ per agricultural season with a threshold of $10 \%$ of significance. In the Senegal Delta, this impact is $€ 505$, but it is not significant. This research therefore suggests that agribusiness production contracts are more favorable to improve the agricultural income of family farms.
\end{abstract}

Keywords: agricultural contract, family farm, impact, income.

DOI: $10.7176 / \mathrm{JESD} / 10-12-10$

Publication date:June $30^{\text {th }} 2019$

\section{Introduction}

Agriculture plays an important role in the economies of African countries. It is an important source of economic growth (Gollin, 2010) and also contributes to poverty reduction (Loayza and Raddatz, 2010) in many developing countries. Agricultural activities are organized and implemented by family farms (Zoundi, Hitimana, \& Hussein, 2005). However, they are confronted by continued population growth, economic liberalization and globalization and deteriorating production conditions. In addition, they face problems in accessing credit and certified inputs and new production techniques and technologies. Therefore, their modernization is essential to increase production and productivity in order to meet the needs of these populations.

Thus, African countries, such as Senegal and Mauritius, pay particular attention to technology transfer and innovative institutional arrangements for farmer's development. Under these conditions, contract farming is introduced into the agricultural sector and is considered an effective means of transferring technology to farmers. It improves agricultural production and marketing, which can lead to an increase in farmers' incomes.

The importance of agricultural contracts in developing countries is a subject of interest and controversy. Some studies indicate that agricultural contracts increase farmers' incomes (Warning and Key, 2002; Miyata et al, 2009; Saigenji and Zeller, 2009; Meshesha, 2011; Nguyen et al. 2015; Sokchea and Culas, 2015). These studies have shown that contract farming helps smallholder farmers improve the cultivation and marketing of their agricultural products

Farmers have access to agricultural inputs, agricultural equipment and machinery, credit and know-how (Cai et al., 2008; Glover, 1984; Sethboonsarng, 2008).

However, contract farming is the subject of much criticisms regarding the unequal relationship between the parties to the contract, an unbalanced bargaining power (Warning and Key, 2002; MacDonald et al., 2004; Sivramkrishna and Jyotishi, 2008). Cai et al. (2008) found that contract farmers earn less income than former contract farmers, non-contract farmers used to participate in the contract. In addition, competition and exclusion of smallholder farmers (Baumann, 2000; CREM, 2008; Sartorius and Kirsten, 2007) as well as agricultural input indebtedness and credit (Eaton and Shepherd, 2001) are among the negative consequences of agricultural contracts.

This paper examines the potential of contract farming as a tool for rural development by revealing its impact on farmers' agricultural incomes in the Senegal Delta River and Mauritius.

\section{Methodology}

\subsection{Data Collection}

The choice of our research areas therefore focused on the Delta of the Senegal River and Mauritius in view of their very favourable climate for crops, their important hydraulic potential, their high growth potential and especially the concentration of important agribusiness in these areas. Study agribusiness is selected randomly, and based on its importance and the existence of contractual arrangements with farmers (Table1). 
Table 1: List of agribusinesses by zone

\begin{tabular}{|l|l|}
\multicolumn{1}{|c|}{ Delta of Senegal } & \multicolumn{1}{c|}{ Mauritius } \\
\hline GDS : Grands Domaines du Sénégal & Médine Agriculture \\
\hline SCL : Société des Cultures Légumière & ENL Agriculture \\
\hline SOCAS : Société de Conserves Alimentaire du Sénégal & Compagnie Labourdonnais \\
\hline WAF : West Africa Farms & SKC Surat \\
\hline CSS : Compagnie Sucrière Sénégalaise & Conserverie Sarjua \\
\hline SOLDIVE & \\
\hline SENHUILE & \\
\hline
\end{tabular}

Beneficiary farmers (treated) were chosen by randomly and according to three criteria: (i) they live in villages close to agribusiness; (ii) they have contracts with agribusiness (iii) they have as main or secondary activity agriculture. Next, we use the non-random harmonized propensity score method to determine the counterfactual sample (control) (Rubin, 1997; Rosenbaum \& Rubin, 1983). Thus, we use survey data from 270 farmers (93 of them treated) in Mauritius and 350 (including 147 treated) in the Senegal River Delta conducted from December 2015 to March 2016.

\subsection{Analysis: Treatment Effects Model}

We evaluate the impacts of adopting contracts $(\mathrm{T})$ on farm income (Y). Define an indicator variable, $\mathrm{T}$, which equals one if a farmer received a treatment (i.e., participated in agricultural contracts of agribusiness) and zero if not. Further, define the outcome variables $\mathrm{Y}$ for each farmer, income in our case. We will sometimes write $\mathrm{Y}_{\mathrm{i}}(\mathrm{T}=$ 1) to emphasize that the $\mathrm{i}^{\text {th }}$ farmer is defined as a farmer who had received a treatment. Either $\mathrm{Y}_{1}$ the income of the treated farmers and $\mathrm{Y}_{0}$ the income obtained from the non-treated:

$$
\left\{\begin{array}{c}
Y 1, \text { if the farmer is treated } T=1 \\
Y 0, \text { if the farmer is untreated } T=0
\end{array}\right.
$$

The observed outcome variable for each group can be defined by the following relationship:

$$
\mathrm{Y}_{\mathrm{i}}=\mathrm{T}_{\mathrm{i}} \mathrm{Y}_{1}+\left(1-\mathrm{T}_{\mathrm{i}}\right) \mathrm{Y}_{0}
$$

The program's average treatment effect on the treated $(\Delta \mathrm{i})$ is the difference between $\mathrm{Y}_{1}$ and $\mathrm{Y}_{0}$ for the set of treated farmers:

$$
\Delta \mathrm{i}=\mathrm{Y}_{\mathrm{i} 1}-\mathrm{Y}_{\mathrm{i} 0}
$$

The expected treatment effect of contract participation is the difference between the actual income and the income if they did not participate: This can be written as:

$$
\Delta^{\mathrm{ATT}}=\mathrm{E}\left(\mathrm{Y}_{\mathrm{i} 1}-\mathrm{Y}_{\mathrm{i} 0} \mid \mathrm{T}_{\mathrm{i}}=1\right)
$$

The effect of treatment on treated is the difference between the average income with treatment

$$
\mathrm{E}\left(\mathrm{Y}_{\mathrm{i} 1} \mid \mathrm{T}_{\mathrm{i}}=1\right) \text {, }
$$

which must be compared with the income they would have had if they had not been treated

$$
\mathrm{E}\left(\mathrm{Y}_{\mathrm{i} 0} \mid \mathrm{T}_{\mathrm{i}}=1\right) \text {. }
$$

Naive comparison between treated and untreated (control):

$$
\begin{gathered}
\mathrm{E}\left(\mathrm{Y}_{\mathrm{i}} \mid \mathrm{T}_{\mathrm{i}}=1\right)-\mathrm{E}\left(\mathrm{Y}_{\mathrm{i}} \mid \mathrm{T}_{\mathrm{i}}=0\right)=\mathrm{E}\left(\mathrm{Y}_{\mathrm{i} 1} \mid \mathrm{T}_{\mathrm{i}}=1\right)-\mathrm{E}\left(\mathrm{Y}_{\mathrm{i} 0} \mid \mathrm{T}_{\mathrm{i}}=0\right) \\
=\mathrm{E}\left(\mathrm{Y}_{\mathrm{i} 1} \mid \mathrm{T}_{\mathrm{i}}=1\right)-\mathrm{E}\left(\mathrm{Y}_{\mathrm{i} 0} \mid \mathrm{T}_{\mathrm{i}}=1\right)+\mathrm{E}\left(\mathrm{Y}_{\mathrm{i} 0} \mid \mathrm{T}_{\mathrm{i}}=1\right)-\mathrm{E}\left(\mathrm{Y}_{\mathrm{i} 0} \mid \mathrm{T}_{\mathrm{i}}=0\right) \\
\mathrm{E}\left(\mathrm{Y}_{\mathrm{i} 1} \mid \mathrm{T}_{\mathrm{i}}=1\right)-\mathrm{E}\left(\mathrm{Y}_{\mathrm{i} 0} \mid \mathrm{T}_{\mathrm{i}}=1\right)
\end{gathered}
$$

is the average effect of the change in income of farmers who benefit from a contract (treated) compared to the hypothetical situation where they would not have been.

$$
\mathrm{E}\left(\mathrm{Y}_{\mathrm{i} 0} \mid \mathrm{T}_{\mathrm{i}}=1\right)-\mathrm{E}\left(\mathrm{Y}_{\mathrm{i} 0} \mid \mathrm{T}_{\mathrm{i}}=0\right) \text { : }
$$

selection bias, reflects an average structural difference between the treated and control group.

The implementation of the propensity score method involves several steps: estimating the propensity score and assessing the quality of the estimated propensity score.

The propensity score is estimated by the Logit model in the first step. This model includes all observed variables that influence treatment selection and the outcome (Jebabli \& Zaiem, 2010).

The Logit model defines the probability associated with the event $Y_{i}=1$, as the value of the distribution function of the logistic law considered in point $\Pi(\mathrm{X})$

$$
\left\{\begin{array}{c}
\operatorname{Logit}(\Pi(X))=\alpha+\beta 1 x 1+\beta 2 x 2+\cdots+\beta n x n \\
\text { ou Logit }(\Pi(X))=\log \left(\frac{\Pi(X)}{1-\Pi(X)}\right) \\
\Pi(X)=\frac{e^{\lambda h(x i)}}{1+e^{\lambda h(x i)}}=\frac{1}{1+e^{-\lambda h(x i)} .}
\end{array}\right.
$$

$\mathrm{h}(\mathrm{xi})$ is formed by linear and higher order terms.

Then, we determine the common support of the propensity score to ensure that for each individual who has accessed the contract we can find at least one individual who has not accessed with the same propensity score.

To build the common support of the propensity score, we use the Nearest Neighbour Matching method. With 
this method, we matched each group of farmers treated with a control group closest to it (Khandker, et al., 2010; Jebabli \& Zaiem, 2010).

Let $\mathrm{T}$ all farmers treated and $\mathrm{C}$ all control units, and such as $Y_{i}^{T}$ and $Y_{j}^{C}$ are the observed results of treated and control, respectively.

C(i) all untraited farmers adapted to all treated farmers $i$ with an estimated value of the pi propensity score. The overall match with the nearest neighbour is (Becker, 2002; Jebabli \& Zaiem, 2010):

The average effect of contracts on farmers is given by:

$$
\mathrm{C}(i)=\left\{j:\|p i-p j\|=\min _{k \in C}\|p i-p k\|\right\}
$$

$$
\begin{gathered}
\Delta^{A T T}=\frac{1}{N^{T}} \sum_{i \in T}\left[Y_{i}^{T}-\sum_{j \in C(i)} w_{i j} Y_{j}^{C}\right] \\
\left\{\begin{array}{c}
w_{i j}=\frac{1}{N^{C}} \text { si } j \in C(i) \\
w_{i j}=0 \text { sinon }
\end{array}\right. \\
w_{i j} \in[01] \text { et } \sum_{j \in C(i)} w_{i j}=1
\end{gathered}
$$

$N^{C}$ is the number of untreated farmers matched with the treated group.

$N^{T}$ Corresponds to the number of farmers in the Treated group.

To assess the impact of agribusiness contracts on farmers' incomes, the equation is:

$Y_{i}$ : agricultural income of farmer $\mathrm{i}$;

$$
\mathrm{Y}_{\mathrm{i}}=\alpha+\beta \mathrm{X}_{\mathrm{i}}+\mu_{\mathrm{i}}
$$

$\mathrm{X}_{\mathrm{i}}$ : variable characteristics of farmers (socio-economic characteristics);

$\alpha$ is a constant and $\beta$ being the vector of coefficients to these variables

$\mu_{\mathrm{i}}$ : error term..

\section{Results and Discussion}

\subsection{Propensity score matching analysis}

The influence of exogenous variables on the probability that a farmer will benefit from an agricultural contract is studied using the Logit model. This sensitivity is measured in terms of elasticity. The degree of significance of the coefficients is the same as at the regression level, since the marginal effects are calculated through the derivative of the estimated probability with respect to the components of the exogenous variables.

The results of the regression show that, although having a positive coefficient, the age of farmers in Mauritius is not significant. In the Delta, this variable is level statistical significance at the $5 \%$ and thus positively influences the probability of farmers participating in agribusiness contracts by $8 \%$.

The sex variable is negative but significant at the 5\% level for Mauritius farmers. It would then lead to a $5 \%$ decrease in the chance of participating in agricultural contracts.

The size of the farm, although it has a positive coefficient, is not significant for farmers in Mauritius and Delta River.

Agricultural labour force is positively significant at the $10 \%$ level in Mauritius and Delta. It therefore induces an increase of $7 \%$ and $5 \%$ respectively the chance of farmer to benefit from a contract. This result can be explained by the fact that agricultural workers constitute the labour force of the farm.

The cultivated land is negative but significant at the 5\% level for Delta farmers.

Education levels for illiterate and primary farmers are positive and significant at the $10 \%$ and $1 \%$ level respectively. This means that Mauritian farmers at the secondary level have respectively a $30 \%$ and $23 \%$ higher chance of benefiting from contracts compared to illiterate farmers and at the primary and university levels. This result could be explained by the fact that educated farmers are more aware of the importance of agricultural contracts. Indeed, education is a good indicator of social progress. It allows farmers to acquire and manage relevant information more effectively.

In Mauritius, the rental and purchase/heritage variables are significant at the $1 \%$ level but negative. This indicates that these would have reduced the farmer's chance of benefiting from a contract by $24 \%$ and $31 \%$ respectively.

In Delta, the land allocation and purchase/heritage are significant at the $1 \%$ level; they would therefore induce a marginal increase of $36 \%$ and $39 \%$ respectively the farmer's chance to benefit from a contract. Indeed, it ensures equality and efficient use of land by providing farmers with access to land and enabling the implementation of a production plan.

In Delta, the income source (fattening, salary, transport and other sources) are positive and significant at the $1 \%$ level and therefore would induce a marginal increase of $35 \%, 84 \%, 37 \%$ and $21 \%$ respectively in the probability of a Mauritian farmer to benefit from a contract. However, in Mauritius, the variables salary, and other sources are significant but negative. Allocating more time to other off-farm activities generates additional income for the farmer. In reality, the second occupation reduces the farmer's time on the farm. Consequently, it has a negative influence on the management of the culture and consequently on technical efficiency. 
Membership of a farmers' organisation is positively significant at the $5 \%$ threshold for farmers in Mauritius. This result can be justified by the fact that groups constitute social networks where farmers often have access to information and those with more information can be easily aware of agribusiness opportunities and be convinced to participate. Olounlade et al. (2014), the presence of these organizations can create dynamism around incomegenerating activities and are considered effective means of improving the level of community development.

The price is statically significant at the respective thresholds of $10 \%$ and $1 \%$ in the Delta and Mauritius. The price variable would positively influence the farmer's probability of participating in agribusiness contracts

Vegetable production is also positive and significant at the 5\% level in Mauritius. The results of the marginal effects describe that it would increase by more than $100 \%$ the chance of the farmer to benefit from a contract with an agribusiness (Table 2). The production agreement allows beneficiary farmers to better estimate their production in terms of area to be planted and quality in order to meet their contractual arrangements but their daily needs. However, this variable is not significant for farmers in Delta. Indeed, they do not sell their entire production, they keep part for their own consumption.

Table 2: Propensity score estimation

\begin{tabular}{|c|c|c|c|c|c|c|}
\hline \multirow[t]{2}{*}{ Variables } & \multicolumn{3}{|c|}{ Marginal effects /Delta of Senegal } & \multicolumn{3}{|c|}{ Marginal effects /Maurice } \\
\hline & $\mathrm{dy} / \mathrm{dx}$ & Std. Err. & $\mathbf{P}>|\mathbf{z}|$ & $\mathrm{dy} / \mathrm{dx}$ & Std. Err. & $\mathbf{P}>|\mathbf{z}|$ \\
\hline Age & 0.0086881 & 0.0029352 & $0.013 * *$ & 0.0023386 & 0.0062813 & $0.583(\mathrm{~ns})$ \\
\hline \multicolumn{7}{|l|}{ Sex : } \\
\hline Female & -0.037534 & 0.291897 & $0.704(\mathrm{~ns})$ & -0.5532529 & 0.0937703 & $0.012 * *$ \\
\hline Labour force & 0.0579744 & 0.0175312 & $0.042 *$ & 0.0703597 & 0.026597 & $0.089 *$ \\
\hline Land Size & -0.0689606 & 0.0211013 & $0.023 * *$ & -0.0251283 & 0.0458599 & $0.641(\mathrm{~ns})$ \\
\hline Farmer Size & 0.00285 & 0.0052566 & $0.588(\mathrm{~ns})$ & 0.0227005 & 0.0213847 & $0.288(\mathrm{~ns})$ \\
\hline \multicolumn{7}{|l|}{ Education } \\
\hline - lliterates & - & & & 0.3093663 & 0.125617 & $0.058 *$ \\
\hline - primairy & 0.0149907 & 0.0792442 & $0.882(\mathrm{~ns})$ & 0.2364413 & 0.0643753 & $0.007 * * *$ \\
\hline - secondairy & -0.0957663 & 0.1268761 & $0.45(\mathrm{~ns})$ & & & \\
\hline -universitaire & -0.1531866 & 0.2497093 & $0.54(\mathrm{~ns})$ & 0.2308271 & 0.1406321 & $0.101(\mathrm{~ns})$ \\
\hline \multicolumn{7}{|l|}{ Land appropriation } \\
\hline - allocation & 0.3687298 & 0.0966609 & $0.001 * * *$ & & & \\
\hline - rental & 0.2133454 & 0.1474793 & $0.148(\mathrm{~ns})$ & -0.2435965 & 0.0624142 & $0.000 * * *$ \\
\hline $\begin{array}{l}\text { - purchase/ } \\
\text { heritage }\end{array}$ & 0.3929741 & 0.1135303 & $0.001 * * *$ & -0.3116401 & 0.0915431 & $0.000 * * *$ \\
\hline \multicolumn{7}{|l|}{ Income source } \\
\hline - trade & 0.0714147 & 0.0749189 & $0.34(\mathrm{~ns})$ & -0.2097394 & 0.1286493 & 0.103 (ns) \\
\hline - fattening & 0.3526936 & 0.1120219 & $0.002 * * *$ & -0.1314697 & 0.1423687 & $0.356(\mathrm{~ns})$ \\
\hline - salary & 0.8458225 & 0.0735363 & $0.001 * * *$ & -0.1234509 & 0.0855147 & $0.073 *$ \\
\hline - transport & 0.371452 & 0.183916 & $0.006 * * *$ & & & \\
\hline - other & 0.2137441 & 0.0835315 & $0.004 * * *$ & -0.2263601 & 0.0741576 & $0.000 * * *$ \\
\hline $\begin{array}{l}\text { Membership of an } \\
\text { organization }\end{array}$ & -0.1332319 & 0.0840436 & $0.113(\mathrm{~ns})$ & 0.2619057 & 0.0735055 & $0.012 * *$ \\
\hline Price & 0.08127 & 0.9457794 & $0.097 *$ & 0.54671 & 0.18350 & $0,005 * * *$ \\
\hline $\begin{array}{l}\text { Vegetable } \\
\text { Production }\end{array}$ & 6.9028907 & 1.605826 & $0.666(\mathrm{~ns})$ & 3.3012325 & 1.3575609 & $0.016^{* *}$ \\
\hline
\end{tabular}

Significance: $*: 10 \% \quad * *: 5 \% \quad * * *: 1 \% \quad(\mathrm{~ns})$ : not significant

We then check the balance of the distribution of the variables between the treated and control group (appendix). This involves ensuring that the match leads to a control population similar to that of the treated.

\subsection{Impact of contract participation on income}

The results reveal that the production contracts impact of $1648 €$ per season on the agricultural income of Mauritius farmers. In addition, the T-stat test shows that this value is significant at the $10 \%$ level (Table 3 ). These results show that participation in the production contracts of potential farmers would have increased agriculture income. There is therefore a positive correlation between farmers' income from production and participation in agricultural contracts. This confirms the hypothesis that farmers improve their income by participating in agribusiness contracts. This increase in income could have an effect on the promotion of modern and competitive agriculture. Untreated farmers therefore have the potential to increase their income by entering into agricultural production contracts with agribusiness

In Delta, the impact of these contracts on farmers' farm income is $€ 505$. However, the result of the T-stat shows that this impact is not significant (Table 3). This means that agribusiness has no statistical effect on farmers' 
incomes. Indeed, according to $89.80 \%$ of the farmers surveyed, these contracts have no effect on their agricultural production. It should also be noted that to ensure the food security of the family, farmers in Delta produce to feed themselves first and then sell the surplus to meet their needs.

Many studies show that contract farmers earn a higher income than non-contractual farmers: Miyata et al (2009) contractualization increases per capita income by $22 \%$ of the average income of apple growers and $45 \%$ of the average income of green onion growers in China; Kumar (2008), income and employment creation is almost double for contract farms; Saigenji and Zeller (2009), contractual participation has a significant effect on income of VND 8000 per day per capita in tea production in northwest Vietnam; Meshesha (2011), contracting organic honey farmers earn about USD 426.7 to 472.8 per year in southwest Ethiopia; Nguyen (2015) Income from rice contract farms in Laos is $1,173 \mathrm{Kip} /$ ha higher than that of independent farms; Sokchea and Culas (2015), contracting farmers' net agricultural income has increased by 1,703,500 riels (425.88 dollars) Kampong Thom province, Cambodia.

However, there are also studies that have shown that contract farmers have lower incomes than noncontractual farmers: Zola et al (2007), the agricultural income of non-contractors is higher in the cultivation of rubber, sugar cane, oil palm, cassava, rice, vegetables, tobacco and cotton is higher in Cambodia; Cai et al. (2008), former contract rice farmers in Cambodia, on average, if they had joined the contract, their profits would have been 0.18 million riel lower than their actual profits; Kumar and Kumar K (2008), livestock incomes are higher on non-contractual farms (13080 rupees) than on contract farms (11683 rupees) the Tumkur district of Karnataka state; Manorom et al. (2011), non-contractual cabbage and corn producers tend to earn slightly higher profits than their contract farming counterparts ( $\$ 896$ versus $\$ 698$ for cabbage, $\$ 1,608$ versus $\$ 1,456$ for corn) in Lao People’s Democratic Republic.

Table 3: Estimation of the impact of contracts on farmers' agricultural income

\begin{tabular}{|l|l|l|l|l|l|l|l|l|l|}
\hline & & \multicolumn{4}{|c|}{ Delta of Senegal } & \multicolumn{4}{c|}{ Mauritius } \\
\hline Variable & Sample & Treated & Controls & Difference & T-stat & Treated & Controls & Difference & T-stat \\
\hline Income & Unmatched & 2012.77 & 2223.71 & -210.94 & -0.45 & 4873.49 & 3255.93 & 1617.56 & 1.96 \\
\hline & ATT & 2012.77 & 1507.98 & 504.78 & 0.81 & 4873.49 & 3225.19 & 1648.3 & 0.88 \\
\hline
\end{tabular}

\section{Conclusion}

In this article, we have analyzed the impact of agricultural contracts on producers' incomes. Thus, we have identified production contracts in Mauritius while in the Senegal River Delta we have more employment contracts. The impact of these contracts on the agricultural income of the treaties is $€ 1648$ in Mauritius with a threshold of $10 \%$ significance. In the Delta, the impact of employment contracts on agricultural income is $€ 505$, but it is not significant. It can therefore be assumed that agricultural production contracts can contribute to improving the agricultural incomes of small producers and consequently to the development of family farming.

One of the implications of these results is that public policies should support the establishment and maintenance of contract farming, especially when it comes to small farmers. This support could take the form of establishing a clear legal framework for contracts between farmers and agro-industrial companies.

Facilitating farmers' organizations and other intermediaries such as cooperatives and non-governmental organizations (NGOs) should be involved in contract farming to facilitate communication and negotiations between farmers and agro-industrial. In addition, public-private extension partnerships should be encouraged to provide extension services to producers through the contract.

\section{References}

Baumann, P. (2000). Equity and Efficiency in Contract Farming Schemes: The experience of Agricultural Tree Crops. ODI working paper 139.

Cai, J., Ung L., Setboonsarng S. and Leung P. (2008). Rice Contract Farming in Cambodia: Empower Farmers to move beyond the contract toward Independence, ADBI discussion paper No. 109.

CREM (2008). Contract Farming in ASEAN Countries: A Fact Finding Study.

Eaton, C. and Shepherd A. W. (2001). Contract Farming: Partnerships for Growth. FAO Agricultural Services Bulletin 145.

Gollin, D. (2010). Agricultural Productivity and Economic Growth in P. Pingali and, R. Evenson (eds.). Handbook of Agricultural Economics, 4, 3825-3866.

Jebabli, I., \& Zaiem, M. H. (2010). Estimation par la méthode d'appariement de l'impact de l'utilisation des moyens de contraception sur la fécondité. Essai, Ecole Supérieure de la Statistique et de l'Analyse de l'Information de Tunis, Tunis.

Khandker, S. R., Koolwal, G. B., \& Samad, H. A. (2010). Handbook on impact évaluation: quantitative methods and pratices, Washington DC: Word Bank.

Kumar, P and Kumar, J. (2008). Contract Farming: Problems, Prospects and its Effect on Income and Employment, Agricultural Economics Research Review, 21, 243-250. 
Loayza, N. V., and Raddatz C. (2010). The composition of growth matters for poverty alleviation, Journal of Development Economics, 93, 137-151.

MacDonald, J., J. Perry, M. Ahearn, D. Banker, W. Chambers, C. Dimitri, N. Key, K. Nelson and L. Southard. (2004). Contract, Market and Prices: Organizing the Production and Use of Agricultural Commodities. USDA Agricultural Economic Report No. 837.

Manorom K., Hall D., Lu X., Katima S., Medialdia M.T, Siharath S., and Srisuphan P. (2011). Cross-Border Contract Farming Arrangement: Variations and Implications in the Lao People's Democratic Republic, Asian Development Bank-ADB, Research Report Series, Volume No. 1 Issue No. 2, 70p.

Meshesha, J.G. (2011). Impact of contract farming on household income of smallholder farmers: The case of organic honey production in South Western Ethiopia, Sheka Zone.

Miyata, S., N. Minot and D. Hu. (2009). Impact of Contract Farming on Income: Linking Small Farmers, Packers, and Supermarkets in China in World Development, 37(11), 1781-1790.

Nguyen A. T., Dzator J., Nadolny A. (2015). Does contract farming improve productivity and income of farmers? A review of theory and evidence, Proceedings of the Australasian Conference on Business and Social Sciences 2015, Sydney in partnership with The Journal of Developing Areas, 341-352.

Olounlade, A., Arouna, A., Diagne, A., \& Gauthier, B. (2014). Evaluation de l'impact des contrats agricoles sur le revenu des producteurs de riz: cas du Bénin, article scientifique, Université d'Abomey-Calavi, AfricaRice, Faculté des Sciences Agronimiques, Cotonou.

Rosenbaum, P.R., Rubin, D. B. (1983). The Central Role of the Propensity Score in Observational Studies for Causal Effects, Biometrika, 70(1), 41-55

Rubin, D. (1997). Assignement to Treatment Group on the Basis of a Covariate, Journal of educational Statistics, 2(1), 1-26.

Saigenji Y. and M. Zeller (2009). Effect of contract farming on productivity and income of small holders: The case of tea production in north-western Vietnam, Contributed Paper prepared for presentation at the International Association of Agricultural Economists Conference, Beijing, China, August 16-22, 16p.

Sartorius, K. and Kirsten J. (2007). A framework to facilitate institutional arrangements for smallholder supply in developing countries: An agribusiness perspective in Food Policy, 32, 640-655.

Sascha O. Becker, A. I. (2002). Estimation of average treatment effects based on propensity scores. Dans H. J. Newton (Éd.), The Stata Journal (pp. 358-377), Stata Press.

Sivramkrishna, S. and Jyotishi A. (2008). Monopolistic Exploitation in Contract Farming: Articulating a Strategy for Grower Cooperation in Journal of International Development, 20: 280-296.

Sokchea A., Culas R. J. (2015). Impact of Contract Farming with Farmer Organizations on Farmers' Income: A Case Study of Reasmey Stung Sen Agricultural Development Cooperative in Cambodia, Australasian Agribusiness Review, 23(1), 1-11.

Warning, M., and Key N. (2002). The Social Performance and Distributional Consequences of Contract Farming: An Equilibrium Analysis of the Arachide de Bouche Program in Senegal. World Development 30 (2), $255-$ 263.

Zoundi, J., Hitimana, L., \& Hussein, K. (2005). Economie familiale et innovation agricole en Afrique de l'Ouest : vers de nouveaux partenariats. Initiative du secrétariat du club du sahel et de l'Afrique de l'Ouest-SCSAO. 
APPENDIX

Graphic 1: Distribution of propensity scores before and after matching Mauritius

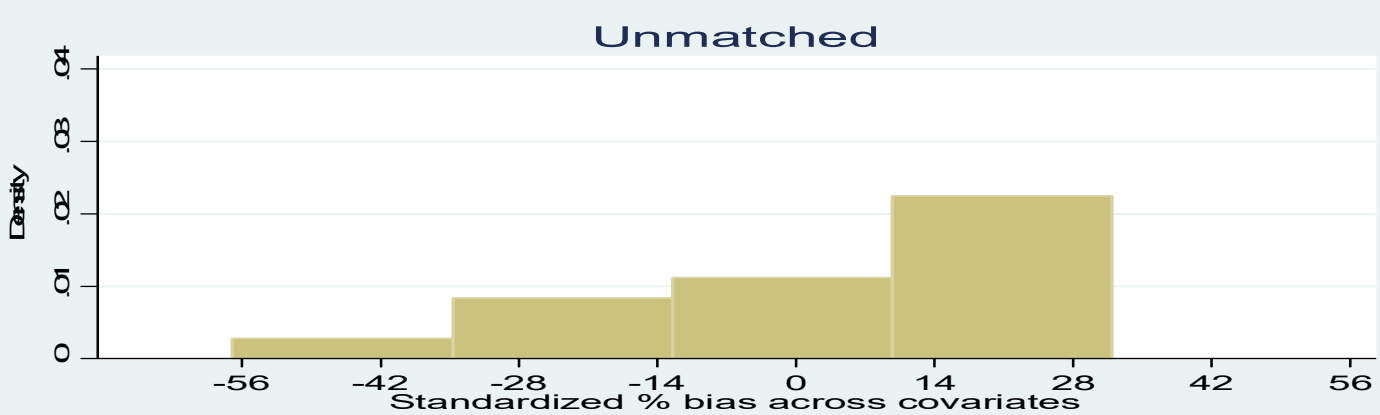

Matched

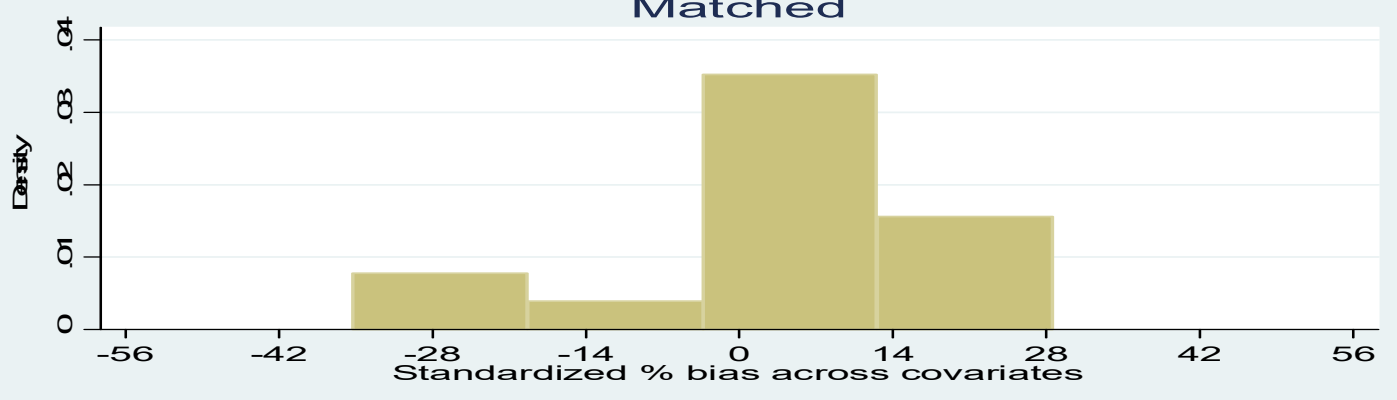

Graphic 2: Zone of common support Maurice

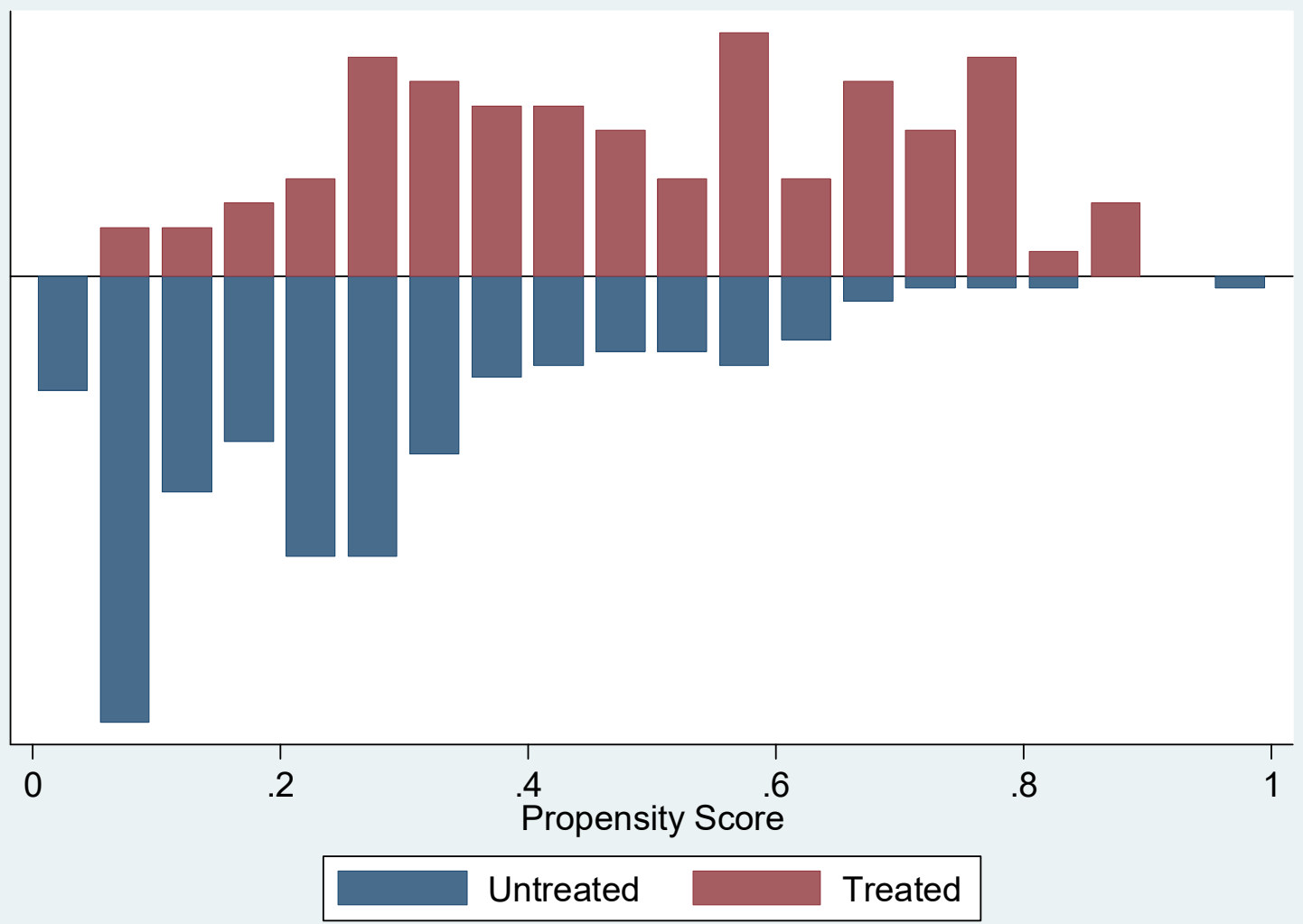


Graphic 3: Distribution of propensity scores before and after matching Delta
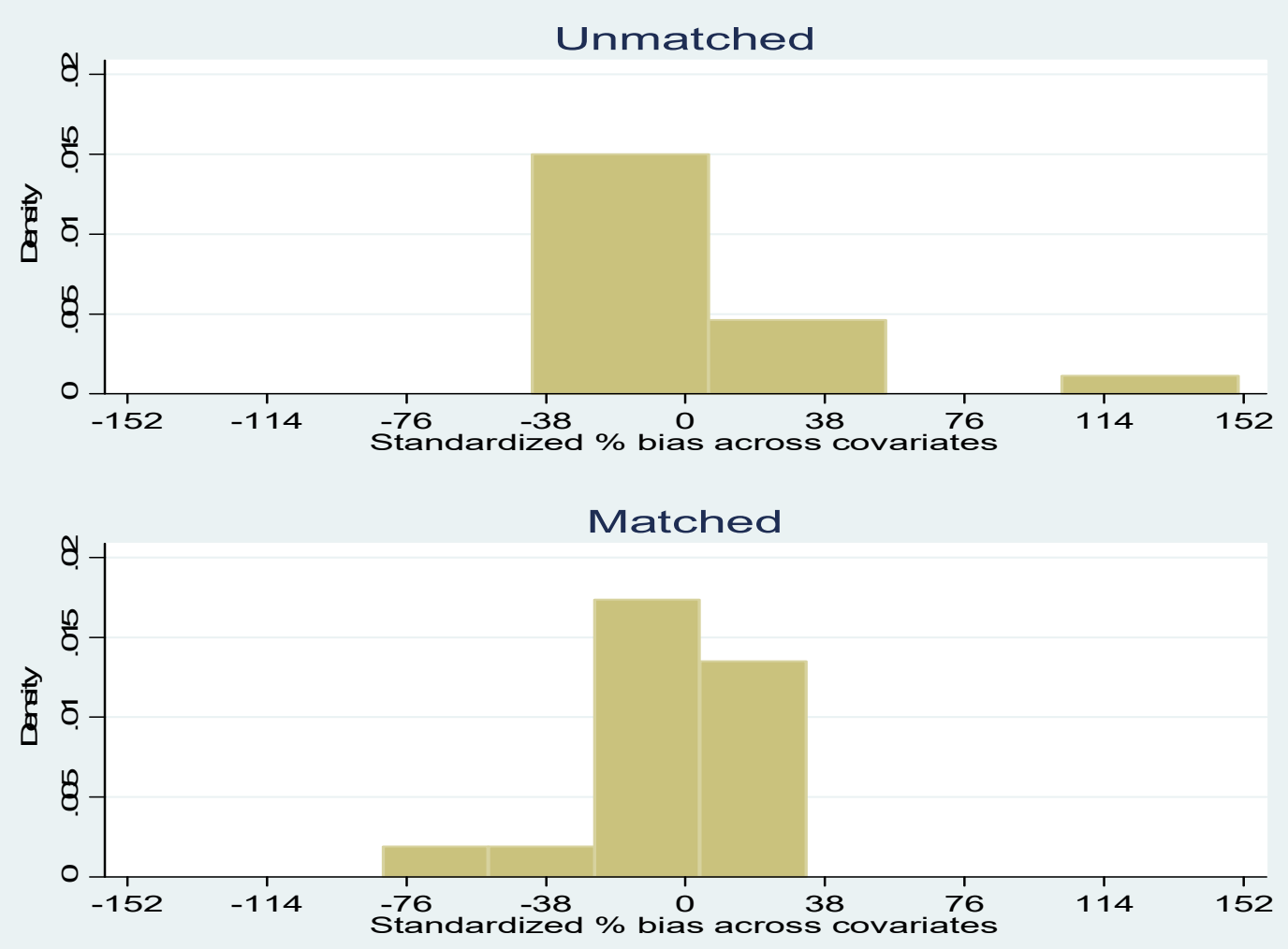

Graphic 4: Zone of common support Delta

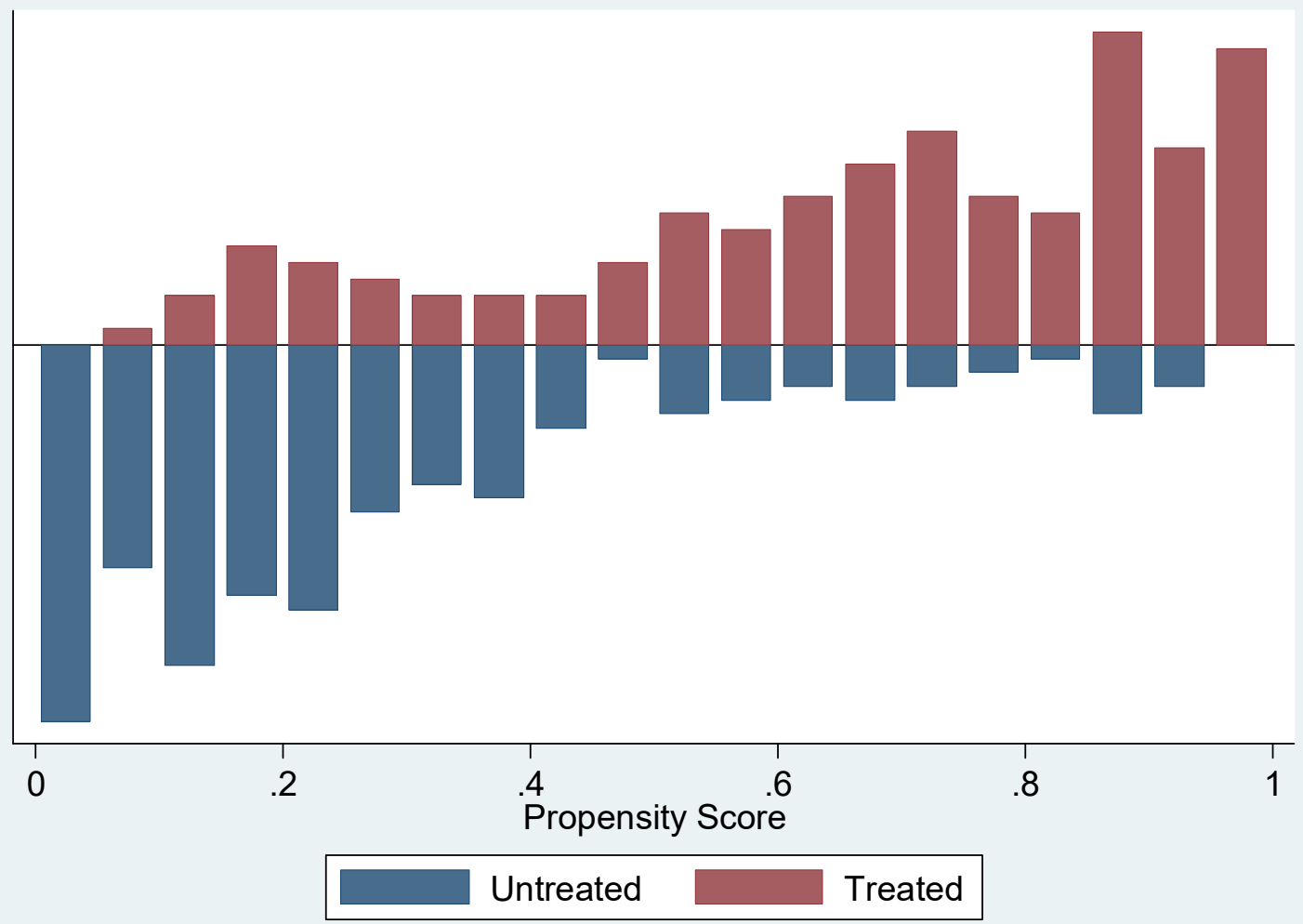

